\title{
Analisis Faktor Pengendali Konflik Keagenan Terhadap Nilai Perusahaan Dengan Kebijakan Dividen Sebagai Variabel Moderasi
}

\author{
Rita Amelinda dan Happy Darmawan \\ Fakultas Ekonomi Universitas Tarumanagara \\ Email:ritaamelinda@gmail.com
}

\begin{abstract}
The purpose of this research is to measure the influence between agency conflict's factors to the value of the firm with dividend policy as the moderating variable. Some of variables which are used in this research such as Free Cash Flow Ratio, Leverage, Return on Asset, GCG's Implementation (CGPI), Dividend Policy, danValue of The Firm (Tobin's Q). This research sample consisted of 126 observations which are the listed company in Indonesia Stock Exchange (IDX) during 2008-2014 period and they also are the company with the best GCG index. The results showed thatFree Cash Flow Ratio, Leverage, Return on Asset, GCG's Implementation (CGPI), Dividend Policy have significant effect simultaneously on Value of The Firm (Tobin's Q). While in partial, only GCG's Implementation (CGPI) which doesn't has significant effect onValue of The Firm (Tobin's Q). On the other hand, dividend policy significantly moderated the influence of the other 4 independent variables to the value of the firm.
\end{abstract}

Keywords: Corporate Governance Perception Index, Good Corporate Governance, Agency Conflict, Leverage, Dividend Ratio, Free Cash Flow, Leverage, Return on Asset, Value of The Firm.

Abstrak: Penelitian ini bertujuan untuk mengetahui pengaruh faktor pengendali konflik keagenan terhadap nilai perusahaan dengan kebijakan dividen sebagai variabel moderasinya. Variabel yang digunakan dalam penelitian ini adalahFree Cash Flow Ratio, Leverage, Return on Asset, Penerapan GCG (CGPI), Kebijakan Dividen, dan Nilai Perusahaan (Tobin's Q). Penelitian ini menggunakan 126 observasi yang merupakan perusahaan yang terdaftar di Bursa Efek Indonesia (BEI) sejak tahun 2008-2014 dan termasuk dalam perusahaan dengan peringkat GCG terbaik. Hasil penelitian menunjukkan bahwa terdapat pengaruh signifikan secara bersama-sama antara Free Cash Flow Ratio, Leverage, Return on Asset, Penerapan GCG (CGPI), Kebijakan Dividen, terhadap Nilai Perusahaan (Tobin's Q). Sementara secara parsial, hanya Penerapan GCG (CGPI) yang tidak berpengaruh secara signifikan terhadap nilai perusahaan. Selain itu, variabel kebijakan dividen dinilai dapat memoderasi secara signifikan pengaruh antara keempat variabel independen terhadap nilai perusahaan.

Kata kunci: Corporate Governance Perception Index, Good Corporate Governance, Konflik Keagenan, Leverage, Dividend Ratio, Free Cash Flow, Leverage, Return on Asset, Nilai Perusahaan.

\section{PENDAHULUAN}

Tujuan utama dari sebuah perusahaan go public dan manajemen mengarah kepada maksimisasi nilai perusahaan yang pada umumnya terilustrasi melalui kesejahteraan kekayaan pemegang saham. Hal ini secara tidak langsung merujuk pada harga saham dan 
dividen yang menjadi titik penilaian dan tingkat pengembalian atas investasi yang diberikan oleh pemegang saham. Nilai perusahaan yang tinggi menjadi salah satu indikator yang pada umumnya ditargetkan investor dan pemegang saham untuk menilai kondisi suatu perusahaan.Sementara bila diamati dari Grafik 1, nilai perusahaan dalam observasi penelitian ini cenderung mengalami penurunan nilai perusahaan selama periode krisis berlangsung.

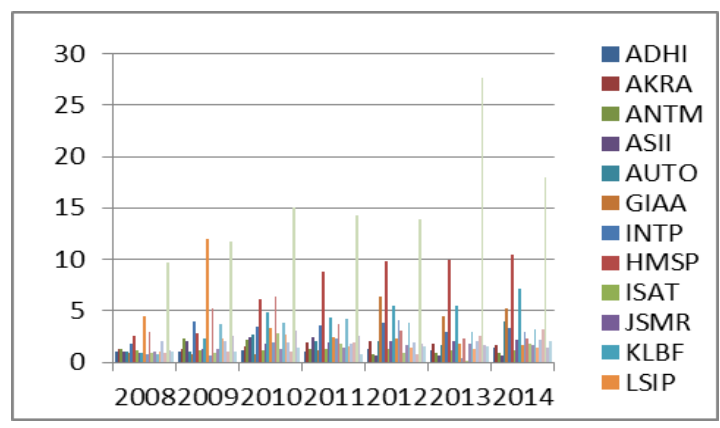

Grafik 1. Data Tobin's Q Perusahaan dengan GCG Terbaik periode 2008-2014 Sumber: data diolah

Penurunan nilai perusahaan ini salah satunya disebabkan oleh konflik keagenan yang berpeluang untuk hadir di dalam manajemen suatu perusahaan. Konflik keagenan terindikasi sebagai kondisi yang akan berdampak negatif bagi manajemen laba dan tata kelola perusahaan. Adanya pemisahan fungsi antara pemilik dan manajemen sering memiliki dampak negatif yaitu keleluasaan manajemen untuk memaksimalkan laba dengan biaya yang ditanggung oleh pemegang saham. Wang (2010) menyatakan bahwa biaya keagenan yang menjadi beban bagi kekayaan pemegang saham Semakin besar free cash flow sebuah perusahaan, maka semakin besar juga kecenderungan konflik keagenan terjadi. Adanya kemungkinan bahwa pemegang saham memiliki motivasi yang kuat dalam mengendalikan perusahaan pada bagian kapasitas yang bukan proporsi mereka juga menjadi peluang timbulnya konflik keagenan. Tindakan ini dapat disebabkan oleh benturan kepentingan maupun asimetri informasi yang terjadi. Misalnya kasus PT. KAI berawal dari perbedaan pandangan antara manajemen dan komisaris, khususnya ketua komite audit. Masalah kasus ini dapat merambah ke konflik keagenan yang rumit bila tidak diselesaikan dengan transparansi. Dalam hal ini, komisaris menolak menyetujui dan menandatangani laporan keuangan yang telah diaudit oleh auditor eksternal. Komisaris meminta untuk dilakukan audit ulang agar laporan keuangan dapat disajikan secara transparan dan sesuai dengan fakta yang ada.

Brealy, Myers, \& Marcus (2007) mengungkapkan hal yang sama dengan Ross, et.al. (2006), mereka menunjukkan bahwa terjadinya informasi yang bersifat asimetri mendorong adanya konflik keagenan. Hal ini disebabkan oleh informasi yang bersifat tidak transparan, dibatasi, atau bahkan ditutupi dari manajer kepada investor atau pihak eksternal lainnya. Asimetri informasi mencerminkan suatu kondisi informasi yang tidak seimbang antara pihak manajemen (agen) sebagai penyedia informasi dengan pihak pemilik. Contoh nyatanya adalah terlihat adanya kejanggalan pergerakan harga saham BII yang mengarah pada adanya informasi pasar yang asimetris (market asymmetric information) karena insider trading. Jensen \& Meckling (1976) berpendapat bahwa teori 
keagenan terjadi atas dorongan konflik kepentingan antara manajer perusahaan, pemegang saham eksternal dan pemegang obligasi. Konflik keagenan di dalam suatu perusahaan kemudian akan menimbulkan agency cost yang berdampak negatif bagi kinerja. Hal ini dikarenakan ketersediaan free cash flow yang dialokasikan kembali untuk mengatur dan mengawasi tindakan atas kepentingan perusahaan (Jensen \& Meckling, 1976). Hundal (2015) menemukan bahwa biaya keagenan yang tinggi berdampak pada kualitas informasi dalam arus operasionalnya.

Dengan demikian, hadirnya Good Corporate Governance dalam pemulihan krisis di Indonesia menjadi hal esensial yang diperlukan, Good Corporate Governance juga mensyaratkan suatu tata kelola yang baik dalam sebuah organisasi. Dua hal yang menjadi konsep utamayaitu pentingnya hak pemegang saham untuk memperoleh informasi dengan akurat dan tepat pada waktunya, serta, kewajiban melakukan pengungkapan (disclosure) secara akurat, tepat pada waktunya, dan transparan (FCGI, 2002). Forum forCorporate governance in Indonesia (FCGI, 2001) menyatakan bahwa tujuan dari corporate governance adalah untuk menciptakan nilai tambah bagi stakeholders.

Crutchley \& Hansen (1989) mengemukakan bahwa proporsi struktur kepemilikan, dividen, dan penggunaan alokasi dana yang dikombinasi dari ekuitas dan utang cenderung mengurangi biaya konflik keagenan tersebut. Berdasarkan Jensen (1986), ada berbagai alternatif yang dapat dilakukan perusahaan untuk mengatasi konflik keagenan. Salah satu alternatifnya yaitu dengan menggunakan utang di dalam struktur modal perusahaan. Dengan adanya proporsi utang dan modal ekuitas membuat dominasi pemegang saham atas perusahaan jelas terlihat tidak mendominasi karena baik dari struktur pembiayaan operasional maupun proyek investasi, perusahaan didanai oleh dua sumber. Tingkat pengembalian atas investasi juga menjadi tolok ukur nilai perusahaan. Investasi dalam hal aset dari sumber dana yang dimiliki akan menunjukkan kinerja manajemen laba yang produktif dan efisien bagi perusahaan (Destriana, 2010). Hal serupa didukung oleh Karaca \& Savsar (2010) bahwa nilai perusahaan didapatkan melalui hasil dari analisis arus kas yang terbentuk dari aset perusahaan. Sementara itu, tingkat pengembalian atas dana kepemilikan saham yang telah diinvestasikan akan dicerminkan melalui dividen yang mengukur tingkat kemakmuran dan keuntungan pemegang saham. Tinggi rendahnya dividen ini juga akan berpotensi menentukan besar kecilnya dampak kebijakan yang ada terhadap konflik keagenan yang terjadi.

Berdasarkan uraian tersebut, nilai perusahaan menjadi hal krusial yang ditargetkan oleh setiap perusahaan sementara kasus konflik keagenan yang menjadi fenomena umum yang terjadi di sebuah perusahaan dalam hal tata kelolanya. Dengan demikian, maka yang menjadi pokok permasalah dalam penelitian ini adalah: (1) Bagaimana pengendalian konflik keagenan melalui Free Cash Flow Ratio, Leverage, Return on Asset, Penerapan GCG (CGPI), Kebijakan Dividen berpengaruh terhadap Nilai Perusahaan (Tobin's Q), dan (2) bagaimana Kebijakan Dividen menjadi indikator yang turut mendukung tinggi rendahnya pengaruh keempat faktor pengendali konflik keagenan terhadap nilai perusahaan.

\section{KAJIAN TEORI}

Pendekatan Nilai Perusahaan. Tujuan utama perusahaan menurut theory of the firm adalah untuk memaksimumkan kekayaan atau nilai perusahaan (value of the firm) (Salvatore, 2005). Memaksimisasi nilai perusahaan sangat penting artinya bagi suatu 
perusahaan, karena dengan memaksimisasi nilai perusahaan berarti juga memaksimisasi kemakmuran pemegang saham yang merupakan tujuan utama perusahaan. Menurut Keown (2005) nilai perusahaan merupakan nilai pasar atas surat berharga utang dan ekuitas perusahaan yang beredar. Brigham \& Ehrhardt (2002) mengungkapkan bahwa nilai perusahaan adalah suatu ukuran maksimisasi kekayaan pemegang saham yang dicerminkan melalui harga saham perusahaan di masa depan sampai tidak terhingga yang didiskontokan. Steward III (2014) mengungkapkan nilai perusahaan menunjukkan kesuksesan manajemen mengalokasi dan mengatur sumber daya dalam memaksimumkan kekayaan pemegang saham dengan membandingkan apa yang mereka korbankan dan dapatkan.

Salah satu pendekatan untuk mengetahui nilai perusahaan yaitu dengan perhitungan Tobin's Q. Rasio ini dinilai bisa memberikan informasi paling baik, karena rasio ini bisa menjelaskan berbagai fenomena dalam kegiatan perusahaan dalam pengambilan keputusan investasi, nilai perusahaan, kinerja manajemen, dan keuntungan. Claessens \& Fan (1999) menyatakan Tobin's Q memberikan wawasan yang lebih luas terhadap pengertian investor.Semakin besar nilai Tobin's Q menunjukkan bahwa perusahaan memiliki prospek pertumbuhan yang baik.Hal ini dapat terjadi karena semakin besar nilai pasar aset perusahaan dibandingkan dengan nilai buku aset perusahaan maka semakin besar pengorbanan investor untuk mengeluarkan pengorbanan yang lebih untuk memiliki perusahaan tersebut.

Kebijakan Dividen sebagai Variabel Moderasi Nilai Perusahaan. Dividen yang dapat dimaknai sebagai proporsi pembagian laba bersih perusahaan didistribusikan kepada pemegang saham atas persetujuan Rapat Umum Pemegang Saham (RUPS) menjadi suatu indikator penentu yang juga harus ditelaah dan diambil keputusannya oleh pihak manajemen seperti besarnya proporsi laba yang akan dibagikan dalam bentuk dividen maupun jenis dividen yang akan dibayarkan.

Gordon \& Lintner mengemukakan bahwa nilai perusahaan dapat dimaksimalkan dengan menetapkan rasio pembayaran dividen yang tinggi yang akan menarik minat investor lebih tinggi terhadap saham sebuah perusahaan (Brigham \& Houston, 2006:71). Dengan demikian, besarnya tingkat dividen akan mempengaruhi harga saham perusahaan yang juga secara tidak langsung berdampak searahdengan nilai perusahaan. Mayoritas dari investor juga memperlakukan dividen sebagai suatu sinyal, di mana kenaikan dividen yang sangat besar menandakan bahwa manajemen merasa optimis atas masa depan perusahaan (bird in the hand theory).

Priya \& Mohnasundari (2016) menyatakan bahwa dalam signaling hypothesis, adanya asimetri informasi membuat investor melakukan prediksi akan kinerja masa depan suatu perusahaan. Dividen yang tinggi menjadi signal peluang profitabilitas di masa depan yang akan berdampak positif pada meningkatnya harga saham. Perusahaan akan berusaha menyesuaikan kondisinya untuk terlihat baik dan berprospek di mata stakeholders terutama investor. Misalnya, bila ditelaah berdasarkan teori dan konflik keagenan, kondisi shareholder rights yang lemah akan membuat perusahaan lebih berusaha keras untuk meningkatkan reputasi mereka di mata pemegang saham dengan dividen yang tinggi. Hal ini akan berdampak pada creditor rights yang lemah sehingga mayoritas kreditur akan berusaha membuat kontrak pembatasan pemenuhan janji hutang perusahaan yang juga berpengaruh terhadap batasan pembayaran dividen bagi pemegang 
saham. Inilah yang menjadi awal pemicu konflik keagenan yang dapat secara tidak langsung menurunkan nilai perusahaan.

Faktor Pengendali Konflik Keagenan. Penelitian Karaca \& Savsar (2010) pada 36 perusahaan industri makanan-minuman-rokok-basic metal yang terdaftar dalam ISE 100 index selama periode 2002-2009 membuktikan bahwa perputaran piutang berpengaruh positif dan signifikan terhadap nilai perusahaan. Sementara, perputaran aset, quick ratio, dan financial ratio, berpengaruh negatif dan kurang signifikan terhadap nilai perusahaan. Lalu, financial leverage dan current ratio berpengaruh secara positif dan kurang signifikan terhadap nilai perusahaan.

Ghodrati \& Hashemi (2014) menemukan hasil penelitian pada 56 perusahaan di Tehran Stock Exchange bahwa free cash flow dan current asset berpengaruh positif dan signifikan terhadap nilai perusahaan sementara sales berpengaruh positif dan kurang signifikan terhadap nilai perusahaan.Free cash flow yang merupakan pengukur kinerja perusahaan yang dicerminkan melalui kas yang tersedia untuk memelihara dan mengembangkan asetnya juga diartikan sebagai sebuah peluang atas kelebihan arus kas yang didiskontokan yang siap digunakan atau diinvestasikan setelah pengalokasian beban modal sebuah perusahaan (Mahadwartha \& Fitri, 2008). Semakin rendahnya nilai dari rasio ini akan menunjukkan bahwa perusahaan memiliki laba yang cenderung digunakan untuk dividen, sementara pembiayaan atas asset dan investasi atas laba akan semakin kecil (Ross, et.al., 2006). Penelitian Hidayah (2014) pada 30 perusahaan properti dan real estate yang terdaftar di Bursa Efek Indonesia periode 2010 - 2012 menemukan bahwa kepemilikan manajerial, profitabilitas (ROA), dan ukuran perusahaan memiliki pengaruh positif dan signifikan terhadap nilai perusahaan sementara leverage memiliki pengaruh negatif tetapi kurang signifikan.

Dengan demikian, indikator free cash flow merupakan salah satu indikator yang penting dalam nilai perusahaan karena free cash flow merupakan cerminan bagi perusahaan untuk melihat peluang dalam meningkatkan nilai sahamnya (Platt, et.al., 2010).

Obradovich \& Gill (2013) melakukan penelitian pada 333 perusahaan di NYSE (New York) selama periode 2009-2011. Obradovich \& Gill membuktikan ukuran yang besar secara negatif berpengaruh terhadap nilai perusahaan. Sementara, dualitas CEO, komite audit, leverage keuangan, ROA, dan kepemilikan internal secara positif mempengaruhi nilai perusahaan pada perusahaan Amerika. Sulong, et.,al. (2013), meneliti nilai perusahaan pada 82 perusahaan di Malaysia (ACE) selama tahun 20072009 membuktikan bahwa ukuran perusahaan, leverage, kualitas audit, dan kepemilikan manajerial secara negatif berpengaruh pada nilai perusahaan. Sementara profitabilitas berpengaruh positif terhadap nilai perusahaan. Pengaruh secara signifikan didapat dari ukuran perusahaan dan kualitas audit terhadap nilai perusahaan.

Ruan, Gary, dan Shiguang (2011) meneliti pada 197 perusahaan yang terdaftad di China Stock Market periode 2002-2007 memberikan hasil pengaruh yang signifikan antara managerial ownership terhadap capital structure dan pengaruhnya berdampak pada firm value. Menurut Brealy, Myers, \& Marcus (2007), leverage menjadi cerminan sebuah risiko dan juga peluang sebuah perusahaan dalam investasi dan operasinya dengan menggunakan utang sebagai sumber pendanaannya. Besarnya leverage ini akan menjadi tanggung jawab pemegang saham juga saat perusahaan kesulitan memenuhi kewajibannya, maka secara tidak langsung kewajiban pemenuhan akan mengurangi 
return yang didapatkan pemegang saham atas investasinya. Penelitian Vintila \& Stefan (2014) pada 334 sampel perusahaan pada periode 2007-2011 menemukan pengaruh postif signifikan antara leverage dan sales growth terhadap nilai perusahaan.

Jensen \& Meckling (1976), membuktikan penggunaan utang kemudian dapat mendatangkan keuntungan bagi perusahaan dengan adanya konsep tax shield dari pembayaran bunga. Hal ini juga akan berdampak pada peningkatan kinerja. Dengan mengadopsi konsep trade off theory yang menggunakan leverage sebagai sumber eksternal modal dalam operasional perusahaan membuat variabel ini memiliki dampak dalam peningkatan earnings per share bagi pemegang saham maupun dampak risiko keuangan yang berpeluang untuk terjadi pada batas tertentu (Ojo, 2012). Bila hal ini dipandang dari sisi positif, dengan adanya utang, perusahaan terawasi dari pengeluaranpengeluaran yang tidak penting.Akan tetapi, manfaat utang cenderung lebih kecil daripada biaya bunga atas utang tersebut, sehingga proporsi utang yang berlebihan dapat membawa perusahaan dalam kondisi financial distress atau bahkan kebangkrutan.Pada satu sisi, hal ini didukung oleh Reyna \& Encalda (2012) yang membuktikan bahwa struktur modal seperti utang akan berpengaruh terhadap kinerja dan nilai perusahaan dengan implikasi yang positif.

Siagian, Sylvia, dan Yan (2013) meneliti 188 sampel perusahaan yang sahamnya diperdagangkan dalam JSX periode 2003-2004 menyatakan bahwa Corporate Governance Index, ukuran perusahaan, dan leverage memiliki pengaruh positif signifikan terhadap firm value. Sementara growth mempengaruhi firm value dengan positif tetapi kurang signifikan, namun disclossure index memiliki pengaruh negatif signifikan terhadap firm value.

Gamayuni (2015) membuktikan penelitiannya pada perusahaan yang terdaftar di BEI pada periode 2007-2009.Penelitian tersebut membuktikan bahwa current asset ratio, ROA, perputaran aset, kebijakan utang dan dividen berpengaruh positif terhadap nilai perusahaan.

Ammann, David, \& Markus (2011) menemukan bahwa corporate governance memiliki pengaruh yang kuat, positif, dan signifikan terhadap firm value pada 6.633 perusahaan dari Governance Metrics International pada 22 negara berkembang periode 2003-2007. Dengan demikian, Good Corporate Governance (GCG) suatu perusahaan menjadi salah satu penentu nilai perusahaan. Di Indonesia, CGPI merupakan indeks yang dinilai secara rutin sejak tahun 2001 untuk menggugah kesadaran perusahaan akan pentingnya GCG. Perusahaan yang mengadopsi dan menerapkan prinsip good corporate governanceakan memberikan sebuah sinyal yang menunjukkan bahwa internal perusahaan berperilaku baik untuk dapat dipercaya, pada akhirnya sinyal ini akan memberi pengaruh pada nilai perusahaan. (Klapper \& Love, 2002; CLSA, 2001).Mekanisme corporate governance ini merupakan sebuah pengendali masalah keagenan dengan tujuan meningkatkan produktivitas dan efisiensi manajerial (Fama \& Jensen, 1983).

Debby, et.al. (2014) meneliti dekatnya korelasi antara good corporate governance dengan firm value. Tujuan dari perusahaan adalah memaksimalkan nilai dari good corporate governance yang akan meningkatkan kesejahteraan pemegang sahamnya. Penelitian tersebut membuktikan bahwa managerial ownership, audit committee, dan independent commissioner berpengaruh negatif dan kurang signifikan terhadap firm value. Sementara ukuran perusahaan dan profitabilitas berpengaruh positif signifikan 
terhadap firm value. Penelitian ini mengambil sampel pada perusahaan sektor perbankan periode 2008-2010.

Menurut Forum for Corporate Governance in Indonesia(FCGI), Corporate Governance Perception Index (CGPI) adalah suatu potensi yang tercermin dari indeks hasil observasi dan survey mengenai implementasi good corporate governance yang berdasarkan pada prinsip fairness, transparency, responsibility, accountability, dan corporate social responsibility. Pemeringkatan penerapan tata kelola perusahaan yang baik pada perusahaan publik dan BUMN di Indonesia.

Pemeringkatan dilakukan berdasarkan survei terhadap praktik GCG menghasilkan skor Corporate Governance Performance Index (CGPI) dalamrating. CGPI merupakan salah satu informasi yang masuk di pasar modal yang diharapkan dapat memberikan dampak berupa sinyal positif terutama yang menyangkut kepercayaan investor atas dana yang diinvestasikan.

Semakin tinggi nilai CGPI akan meningkatkan nilai perusahaan. Kaihatu (2006) yang mengungkapkan bahwa good corporate governance merupakan kunci sukses perusahaan untuk tumbuh dan menguntungkan dalam jangka panjang dan menghadapi persaingan global. Corporate governance adalah suatu integrasi pengendalian internal maupun eksternal yang mengendalikan hubungan manajer dan pemegang saham untuk menekan konflik kepentingan yang terjadi karena pemisahan kepemilikan dan pengelolaan (Williamson, 1984). Tujuan utama dari penerapan prinsip good corporate governance yang baik yaitu sebagai sistem yang mewakili pemegang saham dalam memaksimumkan kekayaannya dan meningkatkan nilai perusahaan melalui harga pasar sahamnya (Monks \& Minow, 2001). Dengan demikian, CGPI yang baik akan mempertahankan nilai untuk stakeholderskarena adanya pengendalian.

Pengembangan Hipotesis. Berdasarkan penjelasan yang disampaikan sebelumnya, maka dapat disimpulkan hipotesis penelitian sebagai berikut:

H1: Free cash flow ratio memiliki pengaruh yang signifikan terhadap nilai perusahaan

$\mathrm{H} 2$ : Leverage memiliki pengaruh yang signifikan terhadap nilai perusahaan

H3: Return on Asset memiliki pengaruh yang signifikan terhadap nilai perusahaan

H4: Penerapan GCG memiliki pengaruh yang signifikan terhadap nilai perusahaan

H5: Kebijakan dividen memiliki pengaruh yang signifikan terhadap nilai perusahaan

H6: Free cash flow ratio, leverage, return on asset, indeks GCG, dan kebijakan dividen memiliki pengaruh yang signifikan terhadap nilai perusahaan

H7: Kebijakan dividen mampu dalam memoderasi pengaruh free cash flow ratio, leverage, return on asset dan penerapan GCG terhadap nilai perusahaan

\section{METODE}

Populasi yang digunakan dalam penelitian ini adalah perusahaan yang memiliki indeks GCG terbaik antara skor 60-100 pada periode 2008-2014 dan terdaftar dalam Bursa Efek Indonesia. Metode yang digunakan dalam pemilihan sampel dalam penelitian ini adalah metode purposive sampling. Pemilihan sampel dipilih secara tidak acak dengan kriteria tertentu sebagai berikut: (1) Jumlah Perusahaan yang memiliki indeks GCG terbaik antara skor 60-100 dan terdaftar di Bursa Efek Indonesia periode 20082014 sebanyak 82 perusahaan. (2) Dari 82 perusahaan yang ada terdapat 19 perusahaan yang bergerak di sektor perbankan akan dieliminasi oleh karena ketidakseragaman 
laporan keuangan. (3)Sebanyak 15 perusahaan dengan satuan mata uang asing juga dieliminasi oleh karena perbedaan konversi mata uang.(4)Sementara terdapat 26 perusahaan dengan ketidaklengkapan data pada periode tertentu juga dieliminasi, (5) dan 4 perusahaan yang tidak memiliki kelengkapan indeks GCG dalam periode penelitian.Dengan demikian, perusahaan yang memenuhi kriteria penarikan sampel sebanyak 18 perusahaan untuk diteliti per tahunnya terhitung dari 2008-2014.

Data yang digunakan dalam penelitian ini adalah data kuantitatif yang diukur dengan suatu skala numerik (angka). Penelitian ini menggunakan sumber data sekunder yang telah dikumpulkan oleh pihak lain dan dipublikasikan kepada masyarakat pengguna data. Sumber data diperoleh dari website resmi Bursa Efek Indonesia (www.idx.co.id) dan penerbitan oleh pihak IICD di SWA mengenai nilai indeks GCG.

Metode Analisis Data. Metode Analisis Data yang digunakan dalam penelitian ini adalah model regresi berganda sebagai berikut:

$$
\mathrm{Q}=\mathrm{a}+\mathrm{b} 1 \mathrm{DER}+\mathrm{b} 2 \mathrm{FCF}+\mathrm{b} 3 \mathrm{ROA}+\mathrm{b} 4 \text { Dividend }+\mathrm{b} 5 \text { CGPI }+\mathrm{e}
$$

Keterangan:

$\mathrm{Y}=$ Nilai perusahaan (Tobin's Q); $\mathrm{a}=$ Konstanta; b1,b2,b3... = Koefisien Regresi Linear yang dapat ditaksir dengan $\mathrm{n}$ buah pasangan data; DER = Leverage (Debt/Equity); $\mathrm{FCF}=$ Free Cash Flow Ratio (FCF/TA); Dividend = Kebijakan Dividend (Div/Earnings); ROA = Return on Asset (Earnings/TA); CGPI = indeks penerapan GCG; e = Error Term (residual)

Tahapan Analisis Data. Statistik Deskriptif. Statistik deskriptif adalah sebuah metode yang digunakan untuk menganalisis dan menyajikan data secara kuantitatif sebagai gambaran keseluruhan data yang menunjukkan karakteristik dalam suatu variabel seperti nilai minimum, maksimum, nilai rata-rata varians, standar deviasi dari data masingmasing variabel yang diobservasi.

1. Uji Asumsi Klasik. Uji asumsi klasik bertujuan untuk mengetahui apakah model regresi yang diperoleh dapat menghasilkan estimator linier yang baik. Pengujian tersebut meliputi: (a) Uji normalitas, (b) Uji Multikolinearitas, (c) Uji Heterokedastisitas, (d) Uji autokorelasi.

a) Uji Normalitas. Uji normalitas ini digunakan untuk menguji apakah dalam sebuah model regresi, variabel dependen dan independen memiliki distribusi yang normal atau mendekkati normal. Pengujian dilakukan dengan uji ScatterP-P Plot. Data residu yang normal dilihat dari distribusi scatter plot yang berada mendekati sekitar garis.

b) Uji Heterokedastisitas. Uji heterokedastisitas bertujuan untuk menguji apakah dalam sebuah model regresi terjadi ketidaksamaan varians dari residual antara satu pengamatan ke pengamatan lainnya. Model regresi dikatakan baik apabila tidak terjadi heterokedastisitas. Uji heterokedastisitas dapat dilakukan dengan Uji Glejser dengan meregresikan nilai absolut residual dan mengabsolutkan variable dependen. Residual adalah selisih antara nilai observasi dan nilai prediksi. Sementara absolut adalah nilai mutlaknya.

c) Uji Multikolinearitas. Pengujian ini mengidentifikasi apakah variable independen yang diteliti memiliki hubungan atau korelasi satu sama lainnya. Apabila terdapat hubungan antarvariabel bebas maka hal ini akan mempersulit peneliti untuk mengetahui variable independen manakah yang mempengaruhi variable dependennya. Pengujian 
asumsi ini dapat dilihat melalui nilai Variance Inflation Factor (VIF). Pada umumnya, nilai VIF yang lebih besar dari 10 akan mengindikasikan adanya multikolinearitas. Jika hal itu terjadi, maka salah satu variable independen harus dieliminasi dari model regresi yang diuji.

d) Uji Autokorelasi. Uji autokorelasi bertujuan untuk mengetahui apakah terjadi korelasi antar anggota serangkaian observasi yang diurutkan menurut waktunya (time series data). Pengujian Durbin-Watson (D-W) dapat digunakan untuk mengetahui hasil uji autokorelasi. Menurut Ghozali (2012:111) dasar penentuannya adalah: (1) Jika $0<\mathrm{D}-\mathrm{W}$ $<$ dL berarti ada autokorelasi positif, (2) Jika dL $<$ D-W $<$ dU atau 4-dU $<$ D-W $<4$-dL berarti tidak dapat diambil kesimpulan, (3) Jika 4-dL $<$ D-W $<4$ berarti ada autokorelasi negatif dan (a) Jika dU $<\mathrm{D}-\mathrm{W}<4$-dU berarti tidak ada autokorelasi positif maupun negatif.

2. Pengujian Hipotesis. Hipotesis merupakan dugaan sementara terhadap rumusan masalah penelitian karena hanya didasarkan pada teori yang relevan namun belum berdasarkan fakta empiris melalui observasi dan pengujian data. Tahap pengujian hipotesis dilakukan untuk melihat apakah variabel independen yang diteliti memiliki pengaruh terhadap variable dependennya. Ada dua pengujian hipotesis yaitu (a) Uji test of significance (uji t statistik) yang bertujuan mengetahui seberapa besar pengaruh variable independen masing-masing secara parsial terhadap variabel dependennya dengan melihat nilai signifikansi thitung dan membandingkannya dengan nilai 0,05 . Suatu pengaruh dikatakan signifikan bila thitung $<0,05(\alpha=5 \%)$ yang menyimpulkan bahwa Ho ditolak dan Ha diterima. (b) Uji signifikansi simultan (Uji Statistik F). Uji statistik F atau yang umumnya disebut uji Anova pada dasarnya menunjukkan apakah semua variabel independen atau bebas yang dimasukkan dalam model mempunyai pengaruh secara bersama-sama terhadap variabel dependen atau terikat. Pengujian dilakukan dengan menggunakan tingkat signifikansi $0,05(\alpha=5 \%)$.

Uii Multiple Correlation (uji R) dilakukan untuk menentukan apakah hubungan antara variabel bebas dengan variabel terikatnya kuat atau lemah, yang dapat dilihat dari nilai $R$ apakah lebih besar atau lebih kecil dari 0,5. Jika lebih besar dari 0,5 berarti hubungan variabel bebas dengan variabel terikat adalah kuat, sementara jika $\mathrm{R}$ lebih kecil dari 0,5 maka hubungan variabel bebas dengan variabel terikat adalah lemah.

Uji Multiple Determination (uji adjusted $\mathbf{R}^{2}$ ) dilakukan untuk mengkaji seberapa besar variabel bebas dapat menjelaskan perubahan pada variabel terikat. Nilai koefisien regresi berganda berada antara 0 sampai dengan 1 . Makin besar nilai adjusted $\mathrm{R}^{2}$ (mendekati 1 ) menunjukkan makin besar kemampuan variabel bebas menjelaskan perubahan pada variabel terikat.

Hasil Empiris. Berikut adalah hasil statistik deskriptif yang memuat nilai maksimum, minimum, standar deviasi, variance, skewness, dan kurtosis atas 126 data observasi yang diteliti selama periode 7 tahun.

Tabel 1. Descriptive Statistics

\begin{tabular}{|c|c|c|c|c|c|c|c|c|c|c|}
\hline & $\mathrm{N}$ & $\begin{array}{l}\text { Mini } \\
\text { mum }\end{array}$ & Maximum & Mean & $\begin{array}{c}\text { Std. } \\
\text { Deviation }\end{array}$ & Variance & Skew & ness & \multicolumn{2}{|c|}{ Kurtosis } \\
\hline & & $\begin{array}{l}\text { Statis } \\
\text { tic }\end{array}$ & Statistic & Statistic & Statistic & Statistic & Statistic & $\begin{array}{l}\text { Std. } \\
\text { Error }\end{array}$ & Statistic & $\begin{array}{l}\text { Std. } \\
\text { Error }\end{array}$ \\
\hline TOBIN'S Q & 126 & .1589 & 27.6315 & 3.134058 & 3.8045020 & 14.474 & 3.553 & .216 & 15.930 & .428 \\
\hline
\end{tabular}




\begin{tabular}{|c|c|c|c|c|c|c|c|c|c|c|}
\hline DER & 126 & .1537 & 6.5975 & 1.401869 & 1.4765221 & 2.180 & 1.861 & .216 & 2.921 & .428 \\
\hline FCF & 126 & $\begin{array}{r}- \\
.7675\end{array}$ & .6830 & .061247 & .1691500 & .029 & -.332 & .216 & 5.786 & .428 \\
\hline ROA & 126 & $\begin{array}{r}- \\
.0489\end{array}$ & .8960 & .147453 & .1381334 & .019 & 2.161 & .216 & 7.718 & .428 \\
\hline DIVIDEND & 126 & .0000 & 1.1198 & .456113 & .2388180 & .057 & .951 & .216 & 1.263 & .428 \\
\hline CGPI & 126 & $\begin{array}{r}64.14 \\
00\end{array}$ & 91.8000 & $\begin{array}{r}79.65523 \\
8\end{array}$ & 6.6070733 & 43.653 & -.162 & .216 & -.740 & .428 \\
\hline $\begin{array}{l}\text { Valid N } \\
\text { (listwise) }\end{array}$ & 126 & & & & & & & & & \\
\hline
\end{tabular}

Sumber: data diolah

\section{Hasil Uji Asumsi Klasik}

a) Normalitas

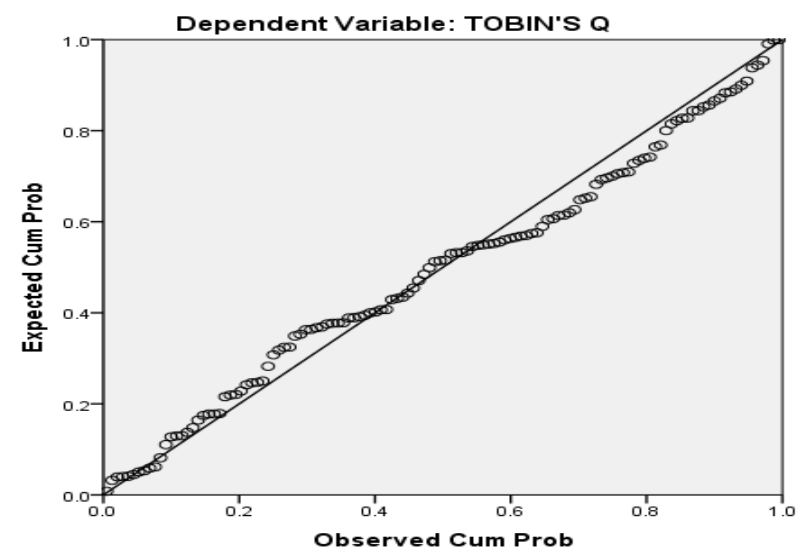

Grafik 2. Normal P-Plot of Regression Standardized Residual Sumber: data diolah

Dari hasil uji normalitas pada grafik 2, terlihat bahwa scatterplot berada di sekitar garis dengan distribusi yang cenderung mendekati garis.Dengan demikian, disimpulkan bahwa pengujian normalitas dapat dikatakan terpenuhi.

b) Hasil Uji Heterokedastisitas

Tabel 2.Uji heterokedastisitas

\begin{tabular}{|c|c|c|c|c|c|c|c|c|}
\hline \multicolumn{2}{|c|}{ Model } & \multicolumn{2}{|c|}{$\begin{array}{l}\text { Unstandardized } \\
\text { Coefficients }\end{array}$} & \multirow{2}{*}{$\begin{array}{c}\text { Standardized } \\
\text { Coefficients } \\
\text { Beta }\end{array}$} & \multirow[t]{2}{*}{$\mathrm{t}$} & \multirow[t]{2}{*}{ Sig. } & \multicolumn{2}{|c|}{ Collinearity Statistics } \\
\hline & & B & $\begin{array}{l}\text { Std. } \\
\text { Error }\end{array}$ & & & & $\begin{array}{l}\text { Tolera } \\
\text {-nce }\end{array}$ & VIF \\
\hline \multirow[t]{6}{*}{1} & (Constant) & 2.686 & 2.425 & & 1.108 & .270 & & \\
\hline & DER & .440 & .131 & .171 & 3.349 & .001 & .868 & 1.152 \\
\hline & FCF & 7.741 & 1.233 & .344 & 6.276 & .000 & .749 & 1.335 \\
\hline & ROA & 14.950 & 1.602 & .543 & 9.334 & .000 & .666 & 1.502 \\
\hline & DIVIDEND & 2.939 & .905 & .184 & 3.246 & .002 & 697 & 1.434 \\
\hline & CGPI & -.053 & .029 & -.091 & -1.820 & .071 & .895 & 1.117 \\
\hline
\end{tabular}

Sumber: data diolah

Berdasarkan hasil dari Tabel 2, dapat disimpulkan bahwa gejala heterokedastisikas pada persamaan regresi ini masih terjadi karena berdasarkan kriteria, masih terjadi signifikansi parsial dari hasil regresi nilai absolut dari unstandardized residual variabel dependen terhadap variabel independennya. 
c) Hasil Uji Multikolinearitas

Tabel 3.Uji Multikolinearitas

\begin{tabular}{|c|c|c|c|c|c|c|c|c|}
\hline \multicolumn{2}{|c|}{ Model } & \multicolumn{2}{|c|}{$\begin{array}{l}\text { Unstandardized } \\
\text { Coefficients }\end{array}$} & \multirow{2}{*}{$\begin{array}{c}\text { Standard } \\
\text { ized } \\
\text { Coeffici } \\
\text { ents } \\
\text { Beta }\end{array}$} & \multirow[t]{2}{*}{$\mathrm{t}$} & \multirow[t]{2}{*}{ Sig. } & \multicolumn{2}{|c|}{ Collinearity Statistics } \\
\hline & & B & $\begin{array}{l}\text { Std. } \\
\text { Error }\end{array}$ & & & & Tolerance & VIF \\
\hline \multirow[t]{6}{*}{1} & (Constan) & 2.686 & 2.425 & & 1.108 & 270 & & \\
\hline & DER & .440 & .131 & .171 & 3.349 & .001 & .868 & 1.152 \\
\hline & FCF & 7.741 & 1.233 & .344 & 6.276 & .000 & .749 & 1.335 \\
\hline & ROA & 14.950 & 1.602 & .543 & 9.334 & .000 & .666 & 1.502 \\
\hline & $\begin{array}{l}\text { DIVI- } \\
\text { DEND }\end{array}$ & 2.939 & .905 & .184 & 3.246 & .002 & .697 & 1.434 \\
\hline & CGPI & -.053 & .029 & -.091 & -1.820 & .071 & .895 & 1.117 \\
\hline
\end{tabular}

Sumber: data diolah

Berdasarkan Tabel 3, dapat disimpulkan bahwa tidak terjadi gejala multikolinearitas pada persamaan regresi yang diuji. Hal ini dilihat dari nilai Tolerance yang mendekati 1 dan nilai VIF $<10$.

d) Hasil Uji Autokorelasi

Tabel 4. Uji Autokorelasi

Model Summary ${ }^{\mathrm{c}}$

\begin{tabular}{llrcrr}
\hline Model & $\mathrm{R}$ & \multicolumn{1}{c}{ R Square } & $\begin{array}{c}\text { Adjusted R } \\
\text { Square }\end{array}$ & $\begin{array}{c}\text { Std. Error of the } \\
\text { Estimate }\end{array}$ & Durbin-Watson \\
\hline 1 & $.854^{\mathrm{b}}$ & .730 & .719 & 2.0184308 & 1.252 \\
\hline
\end{tabular}

a. Predictors: (Constant), DER, DIVIDEND, CGPI, FCF, ROA

b. Dependent Variable: TOBIN'S Q

Sumber: data diolah

Dari Tabel 4, dapat disimpulkan bahwa nilai signifikansi Durbin-Watson dalam penelitian ini sebesar 1,252. Nilai tersebut berada di antara batas nilai DL $(0,70984)$ dan nilai DU $(2,06000)$. Dengan demikian, dapat disimpulkan bahwa penelitian ini masih ada kemungkinan terjadinya autokorelasi.

Hasil Pengujian Hipotesis. Berdasarkan pengujian koefisien regresi berganda seperti pada hasil Tabel 5, dapat disimpulkan bahwa leverage (DER), free cash flow ratio (FCF), return on asset (ROA), kebijakan dividen (Dividend) berpengaruh secara signifikan terhadap nilai perusahaan. Sementara penerapan GCG (CGPI) tidak berpengaruh secara signifikan terhadap nilai perusahaan.

Tabel 5. Koefisien Regresi

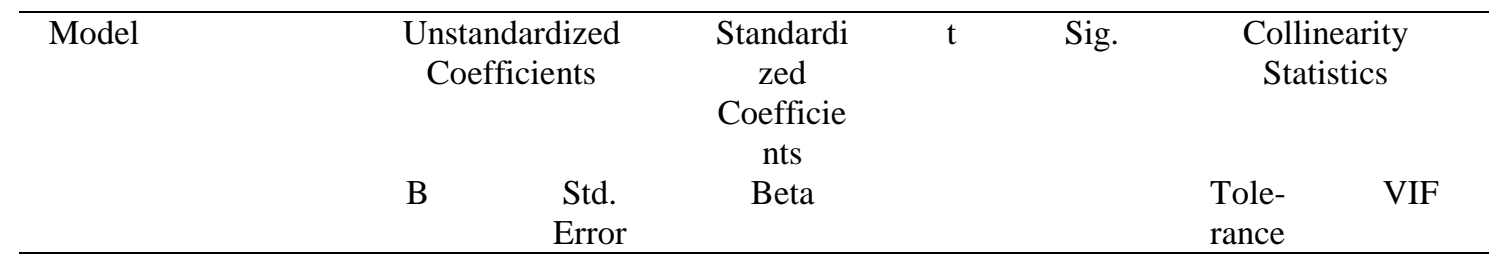


Amelinda dan Darmawan: Analisis Faktor Pengendali Konflik Keagenan...

\begin{tabular}{llrrrrrrr}
\hline 1 & (Constant) & 2.686 & 2.425 & & 1.108 & .270 & & \\
DER & .440 & .131 & .171 & 3.349 & .001 & .868 & 1.152 \\
& FCF & 7.741 & 1.233 & .344 & 6.276 & .000 & .749 & 1.335 \\
& ROA & 14.950 & 1.602 & .543 & 9.334 & .000 & .666 & 1.502 \\
& DIVIDEND & 2.939 & .905 & .184 & 3.246 & .002 & .697 & 1.434 \\
& CGPI & -.053 & .029 & -.091 & - & .071 & .895 & 1.117 \\
& & & & 1.820 & & &
\end{tabular}

Sumber: data diolah

Tabel 6. Hasil Uji F (ANOVA)

ANOVA $^{\text {a }}$

\begin{tabular}{ccccccc}
\hline & & Sum of & & & & \\
& Model & Squares & Df & Mean Square & F & Sig. \\
\hline 1 & Regression & 1320.392 & 5 & 264.078 & 64.819 & $.000^{c}$ \\
& Residual & 488.888 & 120 & 4.074 & & \\
& Total & 1809.279 & 125 & & & \\
\hline
\end{tabular}

a. Dependent Variable: TOBIN'S Q

b. Predictors: (Constant), DER, DIVIDEND, CGPI, FCF, ROA

Sumber: data diolah

Berdasarkan hasil pengujian pada Tabel 6 , terlihat bahwa penelitian ini memiliki hasil signifikan sebesar 0.000. Dengan demikian, bila dibandingkan dengan tingkat signifikansi $\alpha$ 0.05, maka secara bersama-sama, variabel Free Cash Flow Ratio (FCF), Leverage (DER), Return on Asset (ROA), Penerapan GCG (CGPI), dan Kebijakan Dividen (Dividend) mempengaruhi nilai perusahaan dengan tingkat keyakinan $95 \%$.

Tabel 7. Hasil Korelasi Berganda

Model Summary ${ }^{\mathrm{c}}$

\begin{tabular}{lccccr}
\hline Model & $\mathrm{R}$ & $\mathrm{R}$ Square & $\begin{array}{c}\text { Adjusted R } \\
\text { Square }\end{array}$ & $\begin{array}{c}\text { Std. Error of the } \\
\text { Estimate }\end{array}$ & Durbin-Watson \\
\hline 1 & $.854^{\mathrm{b}}$ & .730 & .719 & 2.0184308 & 1.252 \\
\hline a. Dependent Variable: TOBIN'S Q & & & \\
b. Predictors: (Constant), DER, DIVIDEND, CGPI, FCF, ROA \\
Sumber: data diolah
\end{tabular}

Tabel 7 menunjukkan besarnya nilai Adjusted R square yaitu 0,719. Dengan demikian, dapat disimpulkanbahwa 71,9\% tingkat nilai perusahaan dapat dijelaskan oleh variabel Free Cash Flow Ratio (FCF), Leverage (DER), Return on Asset (ROA), Penerapan GCG (CGPI), dan Kebijakan Dividen (Dividend), sementara 28,1\% dijelaskan oleh variabel lainnya. Nilai korelasi (R) pada tabel 7 menghasilkan nilai 0,854 atau $85,4 \%$. Bila nilai $\mathrm{R}$ tersebut dibandingkan dengan 0,5 sesuai maka hal ini menunjukkan bahwa terdapat hubungan yang positif dan kuat antara Free Cash Flow Ratio (FCF), Leverage (DER), Return on Asset (ROA), Penerapan GCG (CGPI), dan Kebijakan Dividen (Dividend) terhadap nilai perusahaan.

Tabel 8 menunjukkan bahwa besarnya adjusted $R$ square pada model 2 mengalami peningkatan dibandingkan model 1 . Model 1 yang menguji pengaruh masingmasing variabel independen terhadap nilai perusahaan sebagai variabel dependennya memiliki kontribusi 71,9\%. Sementara setelah memperlakukan variabel kebijakan dividen sebagai variabel moderasi juga memberikan kontribusi yang lebih sebesar $83,1 \%$ terhadap nilai perusahaan. 
Tabel 8. Hasil Uji Moderasi Model Summary ${ }^{\mathrm{d}}$

\begin{tabular}{|c|c|c|c|c|c|c|c|c|c|}
\hline \multirow[b]{2}{*}{ Model } & \multirow[b]{2}{*}{$\mathrm{R}$} & \multirow[b]{2}{*}{$\begin{array}{c}\mathrm{R} \\
\text { Square }\end{array}$} & \multirow[b]{2}{*}{$\begin{array}{l}\text { Adjusted R } \\
\text { Square }\end{array}$} & \multirow[b]{2}{*}{$\begin{array}{l}\text { Std. Error of } \\
\text { the Estimate }\end{array}$} & \multicolumn{5}{|c|}{ Change Statistics } \\
\hline & & & & & R Square Change & F Change & df1 & df2 & $\begin{array}{l}\text { Sig. F } \\
\text { Change }\end{array}$ \\
\hline 1 & $.854^{\mathrm{b}}$ & .730 & .719 & 2.0184308 & .715 & 79.431 & 4 & 120 & .000 \\
\hline 2 & $.918^{\mathrm{c}}$ & .843 & .831 & 1.5638751 & .113 & 20.974 & 4 & 116 & .000 \\
\hline
\end{tabular}

a. Predictors: (Constant), DER, DIVIDEND, CGPI, FCF, ROA

b. Predictors: (Constant), DER, DIVIDEND, CGPI, FCF, ROA, DERDIV, FCFDIV, ROADIV, CGPIDIV

c. Dependent Variable: TOBIN'S Q

Sumber: data diolah

Hal ini berarti, variabel kebijakan dividen dinilai dapat memoderasi dan mendukung secara signifikan pengaruh antara Free Cash Flow Ratio (FCF), Leverage (DER), Return on Asset (ROA), Penerapan GCG (CGPI), dan Kebijakan Dividen (Dividend) terhadap nilai perusahaan.

\section{PENUTUP}

Kesimpulan. Secara bersama-sama, variabel Free Cash Flow Ratio (FCF), Leverage (DER), Return on Asset (ROA), Penerapan GCG (CGPI), dan Kebijakan Dividen (Dividend) berpengaruh secara signifikanterhadap nilai perusahaan. Kemudian, adanya variabel kebijakan dividen juga dinilai secara signifikan memoderasi keempat variabel independen yang ada terhadap nilai perusahaan sebagai variabel dependennya. Namun, secara parsial, hanya variabel leverage (DER), free cash flow ratio (FCF), return on asset (ROA), kebijakan dividen (Dividend) berpengaruh secara signifikan terhadap nilai perusahaan. Sementara itu, penerapan GCG (CGPI) tidak berpengaruh secara signifikan terhadap nilai perusahaan. Dari pengujian di atas, dapat disimpulkan bahwa 71,9\% tingkat nilai perusahaan dapat dijelaskan oleh variabel Free Cash Flow Ratio (FCF), Leverage (DER), Return on Asset (ROA), Penerapan GCG (CGPI), dan Kebijakan Dividen (Dividend), sementara 28,1\% dijelaskan oleh variabel lainnya. Hubungan pengaruh antara variabel independen yang ada terhadap nilai perusahaan juga dinilai memiliki hubungan yang kuat dan positif sebesar $85,4 \%$.

Keterbatasan penelitian antara lain: (1) Masih terjadi gejala heterokedastisitas pada perusamaan regresi berganda yang diteliti; (2) penelitian ini hanya mengobservasi perusahaan dengan GCG terbaik periode 2008-2014 dengan satuan mata uang rupiah dalam laporan tahunannya; (3) penelitian ini hanya menggunakan 4 variabel independen dan 1 variabel moderasi yang diduga memiliki pengaruh signifikan terhadap nilai perusahaan.

Implikasi. (1) Mengkaji ulang perihal penggunaan variabel yang menimbulkan gejala heterokedastisitas; (2) memperbanyak sampel perusahaan tidak hanya yang memiliki indeks GCG terbaik; (3) menggunakan variabel independen atau moderasi lainnya yang mungkin dapat dikembangkan lagi, seperti growth, struktur kepemilikan, dan lainnya. 


\section{DAFTAR RUJUKAN}

Ammann, Manuel, David Oesch, dan Markus M. Schmid. (2011). "Corporate Covernance and Firm Value: International Evidence". Journal of Empirical Finance, 18 (1).

Brealey, Richard A., Myers, Stewart C., dan Marcus, Alan J. (2007). Fundamentals of Corporate Finance. New York. The McGraw Hill.

Brigham, F. Eugene., dan Ehrhardt, M.C. (2002). Financial Management, Theory and Practice. $10^{\text {th }}$ ed. New York : Thomson Learning, Inc. dan Houston, Joel. (2010). Dasar - Dasar Manajemen Keuangan: Assetials Of Financial Management. Jakarta: Salemba Empat.

Claessens, S., S. Djankov, J. Fan, dan L. Lang. (1999). iExpropriation of Minority Shareholders in East Asiaî. World Bank Working Paper.

Crutchley, C.E., dan Hansen, R.S. (1989). "A Test of the Agency Theory of Managerial Ownership, Corporate Leverage, and Corporate Dividends". Financial Management. 18(4).

Debby, Julia Farah, et.al. (2014). “Good Corporate Governance, Company's Characteristics and Firm's Value: Empirical Study of Listed Banking on Indonesia Stock Exchange". Journal on Business Review. 3(4).

Destriana, Nicken. (2010). Masalah dan Biaya Keagenan.Thesis Trisakti.

FCGI. (2001), Corporate Governance; Tata Kelola Perusahaan. Jakarta. . (2002). The Essence of Good Corporate Governance; Konsep dan Implementasi pada Perusahaan Publik dan Korporasi di Indonesia. Jakarta: YPPMI dan Sinergy Communication.

Fama, Eugene F dan Jensen, M.C. (1983). "Agency Problems and Residual Claims". Journal of Law \& Economics, XXVI

Gamayuni, Rindu Rika. (2015). "The Effect of Intangible Asset, Financial Performance and Financial Policies on the Firm Value". International Journal of Scientific \& Technology Research. 4 (1).

Ghodrati, Hassan, dan Abbas Hashemi. (2014). A Study on Relationship among Free Cash Flow, Firm Value, and Investors' Cautiousness: Evidence from Tehran Stock Exchange. Management Science Letters.

Hidayah, Nurul. (2014). "The Effect of Company Characteristic toward Firm Value in The Properti and Real estate Company in Indonesia Stock Exchange". International Journal of Business, Economics, and Law. 5 (1).

Hundal, Shab. (2015). "Economic Value Added, Agency Costs, and Firm Performance: Theoretical Insights through the Value Based Management Framework". Finnish Business Review Journal.

Jensen, Michael. (1986). Agency costs of free cash flow, corporate finance, and takeovers.

Jensen, M.C. dan W.H. Meckling, (1976). Theory of the firm: Managerial behavior,agency costs and ownership structure. Journal of Financial Economics.

Kaihatu, Thomas S. (2006). Good Corporate Governance dan Penerapannya di Indonesia. Jurnal Manajemen dan Kewirausahaan, 8 (1).

Karaca, Suleyman Serdar dan Arif Savsar. (2010). The Effect of Financial Ratios on the Firm Value: Evidence from Turkey. Journal of Applied Economic Sciences.

Keown, et.al.(2005). Financial Management.10 ${ }^{\text {th }}$ edition. New jersey: Pearson Education 
Inc.

Klapper, L.F., dan I. Love (2002). "Corporate Governance, Investor Protection and Performance in Emerging Markets". Working Paper, Development Research Gloup, The World Bank.

Mahadwartha, Putu Anom dan Fitri Ismiyanti. (2008). Debt Policy, Free Cash Flow Hypothesis, and Balancing of Agency Theory through Ownership: Evidence from Indonesia. Corporate Ownership \&Control. 5(2).

Monks, R. A. G., dan N. Minow. (2001). Corporate Governance, $2^{\text {nd }}$ Edition. Massachussetts: Blackwell Publishers Inc.

Obradovich, John dan Amarjit Gill. (2013). The Impact of Corporate Governance and Financial Leverage on the Value of American Firms. Faculty Publications and Presentations. Paper 25.

Ojo, Akinmulegun. (2012). "The Effect of Financial Leverage on Corporate Performance of Some Selected Companies in Nigeria". Canadian Social Science, 8 (1)

Priya, Vidhya dan M. Mohanasundari. (2016). Journal of Management Sciences and Technology. Vol 3(3).

Platt H, et.al. (2010). Free Cash Flow, Enterprise value, and Investor Caution.North Eastern University Working Paper. Boston.

Reyna-Encalada. (2012). Ownership Structure, Firm Value, and Investment Opportunity Sets: Evidence from Mexican Firm. Journal of Entrepreneurship, Management, and Innovation. 8 (3).

Ross, Stephen A., Westerfield, Randolph W., dan Jordon, Bradford D. (2006). Fundamental of Corporate Finance. New York. The McGraw Hill.

Ruan, Wenjuan, Gary Tian dan Shiguang Ma. (2011). Managerial Ownership, Capital Structure and Firm Value: Evidence From China's Civilian-Run Firms. Australian Business and Finance Journal, 5 (3), article 6, 73-92.

Salvatore, Dominick. (2005). Managerial Economic: Ekonomi Manajerial dalam Perekonomian Global. Edisi Kelima. Terjemahan Ichsan Setyo Budi. Jakarta: Salemba Empat.

Siagian, Ferdinand, Sylvia, dan Yan (2013). "Corporate Governance, Reporting Quality, and Firm Value". Journal of Accounting in Emerging Economies, 3 (1).

Steward III, G. Bennett. (2014). The Definitive Guide to Measuring and Maximizing Shareholder Value: Best Practice EVA. United States: Willey

Sulong, et.al. (2013). "Managerial Ownership, Leverage, and Audit Quality Impact on Firm Performance: Evidence from the Malaysian Ace Market”. Accounting \& Taxation Journal. 5.

Vintila, Georgeta dan Stefan Christian Ghergina (2014). The impact of ownership concentration on firm value. Empirical Study of the Bucharest Stock Exchange Listed Companies. Procedia Economics and Finance. 15.

Wang, George Yungchih. (2010). The Impacts of Free Cash Flows and Agency Costs on Firm Performance. Journal of Service Science \& Management.

Williamson, O.E. (1984). Corporate Governance. Yale Law Journal, 93. 